\title{
Kalanchoë Breeding: Past, Present and Future
}

\author{
Mehmet Uğur Kahraman $^{1^{*}}$ (D), Yeşim Yalçın Mendi² (D), Şenay Karabıyık² (D), \\ Henrik Vlk Lütken ${ }^{3}$ (D), Bruno Trevenzoli Favero ${ }^{3 *}$ (D) \\ ${ }^{1}$ Bat1 Akdeniz Agricultural Research Institute, Vegetables and Ornamental Plants Department, Antalya, Turkey. \\ ${ }^{2}$ University of Cukurova, Faculty of Agriculture, Department of Horticulture, Adana, Turkey. \\ ${ }^{3}$ University of Copenhagen, Faculty of Science, Department of Plant and Environmental Sciences, Section for Crop Sciences, Taastrup, Denmark
}

\begin{abstract}
Kalanchoë cultivars rank as one of the most sold potted ornamental plants in the world. Among its key features that sustain high market interest are the long flowering period, abundance of flowers, thick and glossy leaves, easy maintenance and less water requirement compared to other potted plants. In breeding studies of Kalanchoë, plants with different flower colors such as white, cream, yellow, orange, red, pink and purple were developed. Moreover, double-flowered cultivars (comprising a large number of petals), more compact and cultivars with larger flowers were also obtained. Novel morphological characteristics are always in high demand in the market of ornamental plants. Increasing the variation in the gene pool with different species played a major role in the development of these characteristics. Nowadays, not only potted cultivars are launched but also cut flower cultivars have been developed and presented to consumers. Besides conventional breeding and interspecific hybridization, biotechnological methods, which have a promising future, are used to develop morphological characteristics of Kalanchoë.
\end{abstract}

Keywords: Breeding, Crassulaceae, flower characteristics, hybridization, pollination biology, succulent plants.

\section{Resumo}

Hibridização de Kalanchoë: Passado, Presente e Futuro

As cultivares de Kalanchoë são consideradas uma das plantas ornamentais em vasos mais vendidas do mundo. Entre suas principais características que sustentam o grande interesse do mercado estão o longo período de floração, abundância de flores, folhas grossas e brilhantes, fácil manutenção e menor necessidade de água em comparação com outras plantas em vasos. Nos estudos de melhoramento de Kalanchoë, plantas com diferentes cores de flores como branco, creme, amarelo, laranja, vermelho, rosa e roxo foram desenvolvidas. Além disso, também foram obtidas cultivares com flores duplas (com grande número de pétalas), mais compactas e cultivares com flores maiores. Características morfológicas inovadoras estão sempre em alta demanda no mercado de plantas ornamentais. $\mathrm{O}$ aumento da variação no pool gênico com espécies diferentes desempenhou um papel importante no desenvolvimento dessas características. Hoje em dia, não apenas as cultivares em vasos são lançadas, mas também as cultivares de flores de corte foram desenvolvidas e apresentadas aos consumidores. Além do melhoramento convencional e da hibridização interespecífica, métodos biotecnológicos, de futuro promissor, são utilizados para desenvolver características morfológicas de Kalanchoë.

Palavras-chave: Melhoramento, Crassulaceae, características florais, hibridização, biologia da polinização, plantas suculentas

\section{Origin and History}

The Kalanchoë genus is naturally distributed in regions with a tropical climate, mostly on Madagascar, which is considered to be the epicentre, East and South Africa, South America, India, the Arabian Peninsula and Southeast Asia. The phonetic transcription of the word Kalanchoë has its origin in China. «Kalan Chauhuy» means «falling to the ground and growing) in the Chinese language (Smith et al., 2019) resembling a clear allusion to the viviparous trait observed in many Kalanchoë species (Izumikawa et al., 2007). Another consideration about the origin of its name originated in India; Kalanka $=$ spot, rust; chaya $=$ gloss. This is due to the bright and showy leaves of the $K$. laciniata in India. (Descoings, 2003; Smith et al., 2019). The French botanist Henri Perrier de la Bathie first discovered $K$. blossfeldiana, the species within this genus with most traded cultivars, in 1924 on the slopes of the Tsaratanana Mountain on Madagascar (Perrier, 1928). During his discovery, Perrier took the plants he collected from two

"Corresponding authors: ugurkahramannn@gmail.com, btf@plen.ku.dk 
locations into cultivation. Later, when Perrier returned to Paris, he transferred his collection to the garden. When collecting the plants, he thought that it was $K$. globulifera. While cultivating the plants in Paris, he noticed that the plant from one location exhibited small yellow flowers; therefore, it showed the characteristics of $K$. globulifera as expected. However, he observed that the plants collected from the other location grew larger and the flowers were bigger and red. Perrier considered this red and large flowering plant as a variety under $K$. globulifera and named as $K$. globulifera var. Coccinea. Unlike the other species, this plant, which the botanist called a variety, was found in a semi-shaded area in a forest at an altitude of 1,800-20,00 m (van Voorst and Arends, 1982). Perrier sent its seeds to various botanical gardens in Europe and America after the plant bloomed and self-fertilized. One of the gardens where seeds were sent was the Rostock Botanic Garden in Germany. Robert Blossfeld, who worked as a gardener in the Rostock Botanic Garden, started to produce and grew it as a potted plant after acquiring the plant material. Later, in 1934, botanist Karl von Poellnitz saw that the plant had been propagated by Blossfeld and grown as $K$. globulifera var. coccinea. He, however, realized that this was a separate species that differs from $K$. globulifera and named it $K$. blossfeldiana (Figure 1) (von Poellnitz, 1934; van Voorst and Arends, 1982).
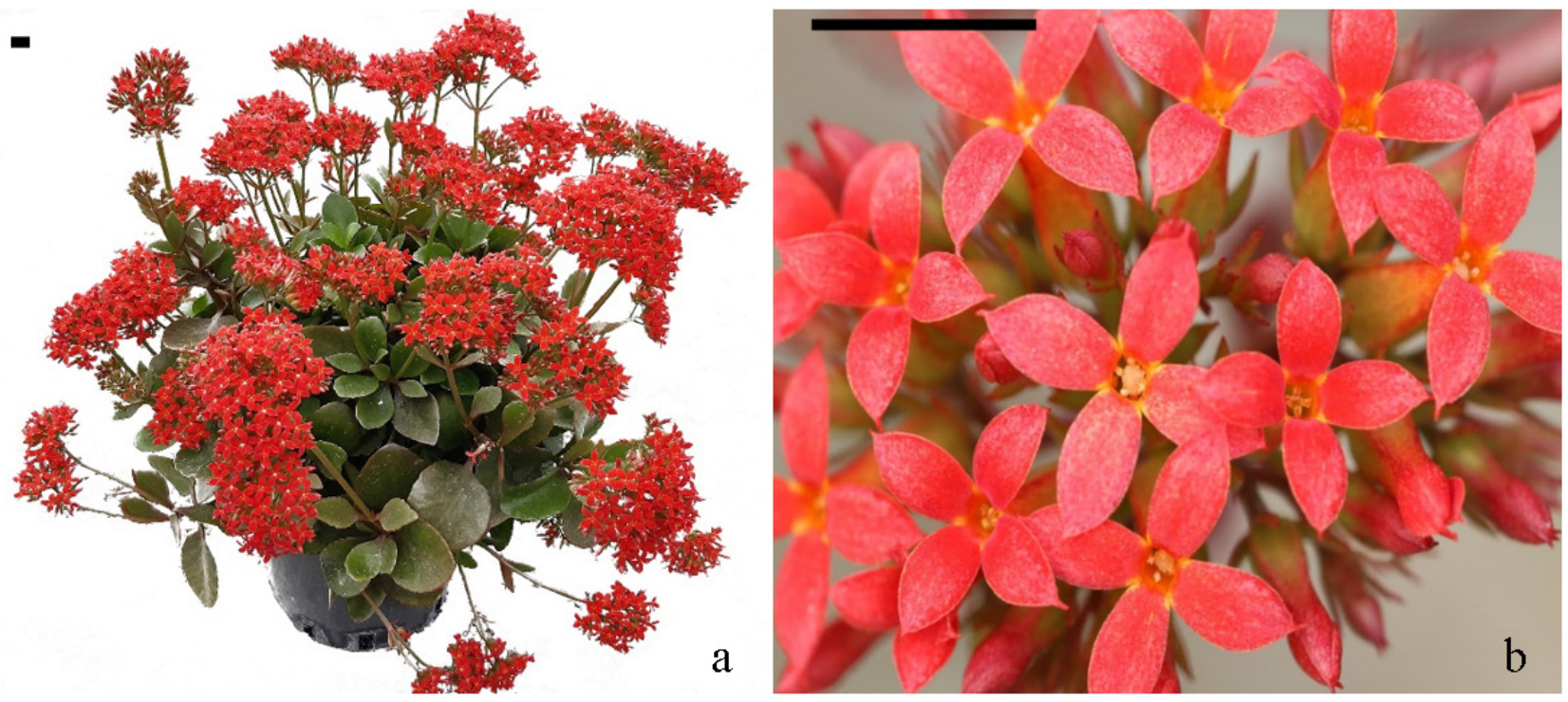

Figure 1. Kalanchoë blossfeldiana derived cultivar, (a) top view and (b) flower details. (Scale bars $=10 \mathrm{~mm}$ ).

The production of $K$. blossfeldiana and the development of new cultivars derived from this species began in 1930s. In these years, the producers cultivated the plants obtained from the self-fertilized plants from the above mentioned material. Since the gene pool was limited and there was no interspecific hybridization, new cultivars were solely selected based on this population. The first cultivars of Kalanchoë were mostly diploid and propagated by seed. At that time, the vegetative development phase was extensive and the plant was much higher. For this reason, the first selection studies in Kalanchoë were in the direction of compact plant selection (van Voorst and Arends, 1982; Mackenzie et al., 2018). In the following years, cultivars with different characteristics were developed by interspecific hybridization. The first interspecies hybrid was obtained in 1939 by hybridization of K. blossfeldiana and $K$. flammea. After the Second World War, breeding studies continued and focused on hybridization between species. Hence, new cultivars were developed by crossing $K$. blossfeldiana with different Kalanchoë species such as K. grandiflora, K. schumacheri, K. kirkii and K. manginii (van Voorst and Arends, 1982). In addition to scientists and researchers, private companies have continuously carried out breeding programs and developed cultivars with distinct characteristics. These cultivars, which have been obtained using the $K$. blossfeldiana plant as the maternal parent, exhibited novel characteristics from the different species it was crossed with. Breeding in Kalanchoë has been carried out from past to present and generated a plethora of cultivars with multiple characteristics such as different colors, double colors, compact growth, a higher number of flowers per plant, a larger number of petals per flower, and long-term flowering (van Voorst and Arends, 1982; Izumikawa et al., 2007; Mackenzie et al., 2018). The most important factor for the development of different characteristics in Kalanchoë cultivars is the success achieved by interspecific and intersectional hybridization.

\section{Taxonomy and Morphology}

Kalanchoë is a perennial succulent plant belonging to the Crassulaceae family. Succulent plants, which have thick and fleshy parts (especially leaves), are resistant to arid climate and soil conditions and present high water holding capacity. These plants can easily store water in plant parts such as leaves or stems. Succulent plants include 
around 60 different plant families such as Cactaceae, Agavoideae, Aizoaceae and Crassulaceae (Eggli, 2003; Royal Horticulture Society, 2021).

Nowadays, it is accepted that there are 33 genera and nearly 1400 species belonging to the Crassulaceae family. This great diversity contains many morphological features such as different forms of plant, leaf and flower structures. Geographically, the Crassulaceae family spreads over a variety of areas and is found on every continent (except Antarctica), especially in dry and hot regions. There is a wide geographic and environmental range from wetlands to cliffs in hot regions, from densely shaded dark forests to large plains. While some species can withstand cold weather, others have a clear preference for tropical and subtropical climates (Eggli, 2003).

The Kalanchoë genus includes approximately 140 species and the species exhibit growth of semi-shrub, shrub and rarely small trees in nature. In addition to being perennial, sometimes annual species are also found. The plants in the genus are generally terrestrial and only rarely epiphytic (Allorge-Boiteau, 1996). The roots are mostly fibrous and only rarely thickened to tuberous. The leaves are with or without petiole, and their arrangement is in the form of the opposite or opposite decussate. Similarly, the leaf shapes and sizes vary widely and the leaf margins are generally entire, but crenate, serrate and dentate ones are also found. The common feature of all species is that they have fleshy leaves. In some species, the leaves are also hairy. Furthermore, some species have viviparous plantlets forming on the edge of the leaves, e.g. $K$ daigremontiana (Figure 2) and $K$. delagoensis. These plantlets are a valuable mean of vegetative propagation that assist in the spread of the plant (Gehrig et al., 2001; Descoings, 2006).

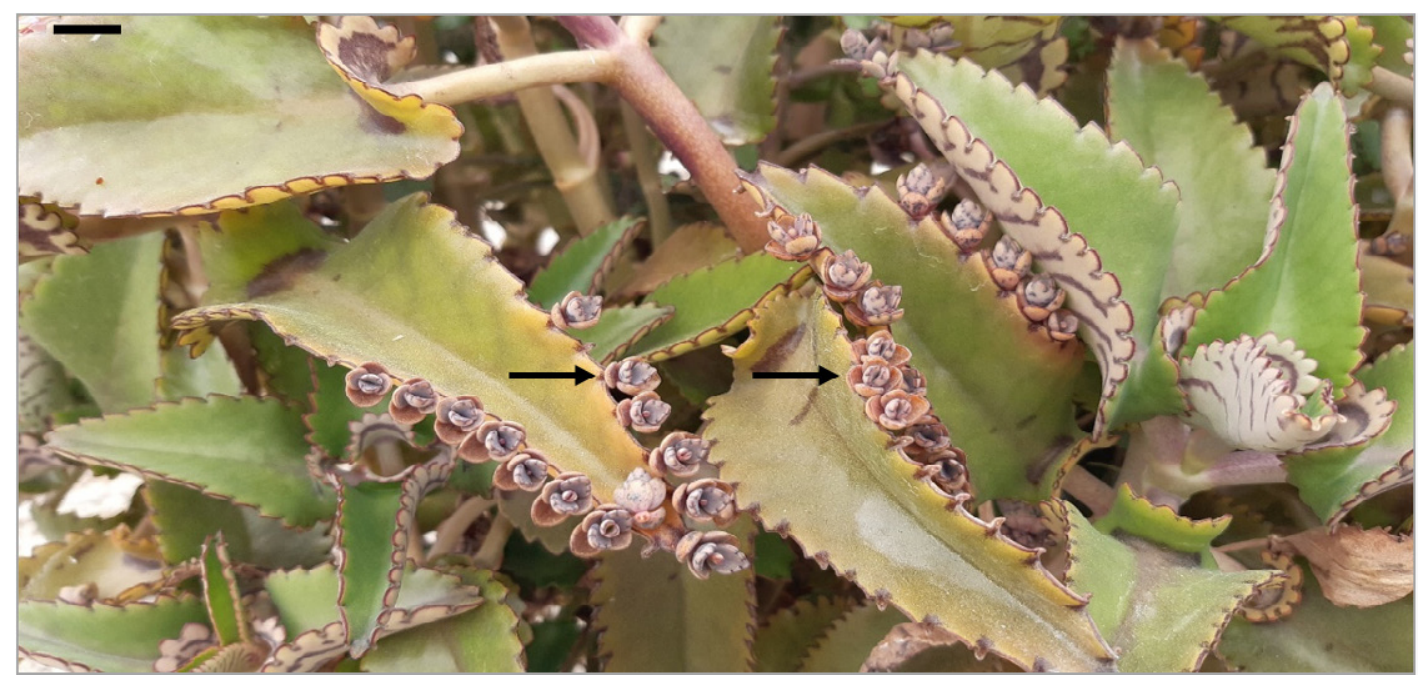

Figure 2. Kalanchoë daigremontiana and viviparous plantlets (black arrows). (Scale bar $=10 \mathrm{~mm}$ ).

The systematics of the Kalanchoë genus is complex and is still not clear and botanists often disagree on this issue. Hamet Raymond, a well-known botanist for the Madagascar flora, first raised this matter in 1907 and officially grouped Bryophyllum under the Kalanchoë genus rather than being a separate genus, which remained being questioned for many years ahead (Chernetskyy, 2011). Boiteau and Allorge-Boiteau in 1995 put forward various opinions and tried to group the species, which are difficult to distinguish and classify, in different ways. Descoings (2003) divided the Kalanchoë genus into two separate sections as Kalanchoë and Bryophyllum (including the species Kitchingia). Furthermore, based on morphological, anatomical, embryological, karyological, phytogeographic and molecular analyzes, Descoings (2006) divided the Kalanchö genus into three sub-genera as Bryophyllum, Kalanchö̈ and Calophygia. He indicated that there are intermediate species that have characteristics of both Kalanchoë and Bryophyllum to the subgenus Calophygia. While Kalanchoë species that are present in Africa have a more homogeneous structure, those in Madagascar differ considerably (Smith et al., 2019). Studies are ongoing to reveal the taxonomy of the Kalanchoë genus in more detail. However, the most proper taxonomic division is accepted as into three sections, which are Kalanchoë, Bryophyllum and Kitchingia (Chernetskyy, 2011). Moreover, in breeding studies, researchers accept the Kalanchoë genus with two sections as Kalanchoë and Bryophyllum as in this paper.

\section{Economic Importance}

In recent years, Kalanchoë has become a popular ornamental plant in the world, especially as a potted plant. Kalanchö is a highly sought-after succulent plant with its durable and long-lasting flowers, low maintenance, and thick, shiny and showy leaves. The genus comprises a plethora of species, varieties and cultivars that are traded in different flower colors such as red, orange, pink, yellow, white and purple. These cultivars can differ in both color and number of petals (single; 4 petals or double or even 15-35 petals, see section 3). Moreover, $K$. blossfeldiana ranked fourth most sold in the world's largest flower auction, Royal FloraHolland (Netherlands), in 2020, after Phalaenopsis orchids, potted flower arrangements (more 
than one plant in a pot), and Anthurium with 85 million items and 61 million Euros turnover (Royal FloraHolland, 2021).

The plant can be produced year-round by using artificial lighting and darkening as its flowering is photoperiodic responsive, being a short-day plant. In this way, Kalanchö can be found on the market throughout the year. Especially newly developed cultivars are sold under a guarantee of approximately 6 weeks flowering (Queen Flowers, 2021), which increases its consumer attractiveness and boost sales on the market. Additionally, the plant continues to be attractive after the end of flowering, because of the beautiful long-lasting foliage. Although the plant is generally used as a potted plant today, its use as a cut flower has been increasing in Europe, especially in recent years (Floral Daily, 2016). Moreover, there is an increase in its consumption as a novelty cut flower. The long life of the vase, ca. 3 weeks offers a significant advantage to cut flower consumers and producers (Queen Flowers, 2021).

\section{Carbon Fixation Pathways}

Crassulacean Acid Metabolism takes its name from the Crassulaceae family, which includes the Kalanchoë genus because it was first seen in plants belonging to it. The Crassulaceae family is one of the best-known succulent plants families (Gehrig et al., 2001; Smith et al., 2019). Most succulent plants have Crassulacean Acid Metabolism (CAM) that presents a timely division between $\mathrm{CO}_{2}$ sequestration and its biochemical mechanisms for carbon fixation known in other plants. This timely division in CAM plants is characterized as opening stomata at night and sequestering $\mathrm{CO}_{2}$ in the form of malic acid, stored in the vacuole (Hultine et al., 2019). Moreover, the accumulation of $\mathrm{CO}_{2}$ as malic acid was perceived since ancient times as succulent plants tasted more acidic in the morning than in the afternoon. The strategic evolution of the CAM plants is directly connected to their surrounding habitats, where water was scarce, e.g., erratic or seasonal rainfall, thus water consumption must be minimized in order to sustain physiological processes (Smith et al., 2019). Therefore, opening stomata at night enabled efficient water usage by limiting transpiration during the day and at the same time provided the needed accumulation of $\mathrm{CO}_{2}$ within the plant tissue to allow photosynthesis to occur. As opposed to regular C3 plants that keep stomata open in order for gas exchange to happen and photosynthesis to occur simultaneously (Kumar et al., 2017). In more detail; once CAM plants open their stomata at night and allow $\mathrm{CO}_{2}$ to enter the leaves, $\mathrm{CO}_{2}$ binds to oxaloacetate with the help of PEP carboxylase and turns into malate or a different organic acid, accumulating in the vacuole of parenchyma cells. The accumulated organic acid formed in the vacuole is the starting point for the CAM plants to continue to photosynthesize while keeping the stomata closed during the day. The vacuoles become large and can take up to $90 \%$ of the cells' volume and the organic acid accumulation increases the internal osmotic potential, also improving water absorption and storage (Yang et al., 2017). Subsequently and during the day, the $\mathrm{CO}_{2}$ is released and enters the usual C3 carbon fixation route. It has been shown that Kalanchoë plants evolved from a C3 ancestor, thus its species range from predominately $\mathrm{C} 3$ to exclusively CAM metabolism, while there are species that inter-change between these two (Kluge et al., 1993; Gehrig et al., 2001).

\section{Flower Morphology, Pollination Biology and Ploidy}

Plant species belonging to the Kalanchoë genus usually have a terminal flower structure and rarely contain axillary flowers. The flowers are hermaphrodite and may be few or many depending on the species. Inflorescence can be corymb, cymose or paniculate. The flowers are pedicellate usually erect and pendent. Furthermore, in plant species belonging to the Kalanchoë genus, the flowers have four petals and are brightly colored. There are eight stamens and four carpels in the flowers (Descoings, 2003). Flowers belonging to the Kalanchoë species show protandrous characteristics, thus, male organs in the flower mature earlier than female organs. There are eight stamens in the flower and these organs are not at the same level in the position that four of them are placed in a lower position and the other four in the upper. The lower anthers of stamen first dehisce and give pollen (Figure 3). In this process, as the flower matures, the style elongates, papillae cells start to lose their arrangement and start to form stigmatic exudates providing pistil receptivity (Figure 4). Therefore, if the stigma is not pollinated in the first stage, it can be self-pollinated by the young stamens in the next period (Hickey and King, 1988). 


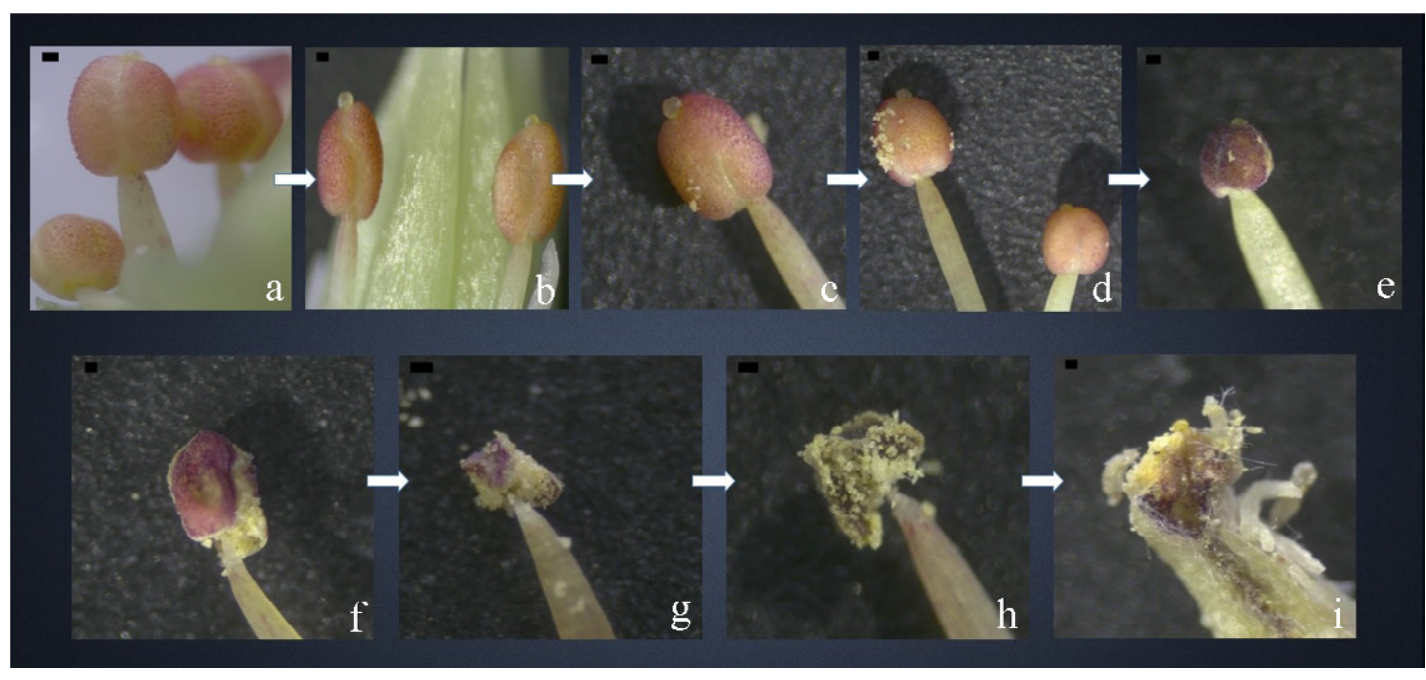

Figure 3. Development stages of anthers of flowers belonging to Kalanchoë blossfeldiana. (a) short filament stage, (b) anthers start to elongate, (c, d) anther dehiscence, (e, f, g) pollen shedding, $(\mathrm{h}, \mathrm{i})$ end of pollen shedding. (Scale bars $=0.1 \mathrm{~mm})$.

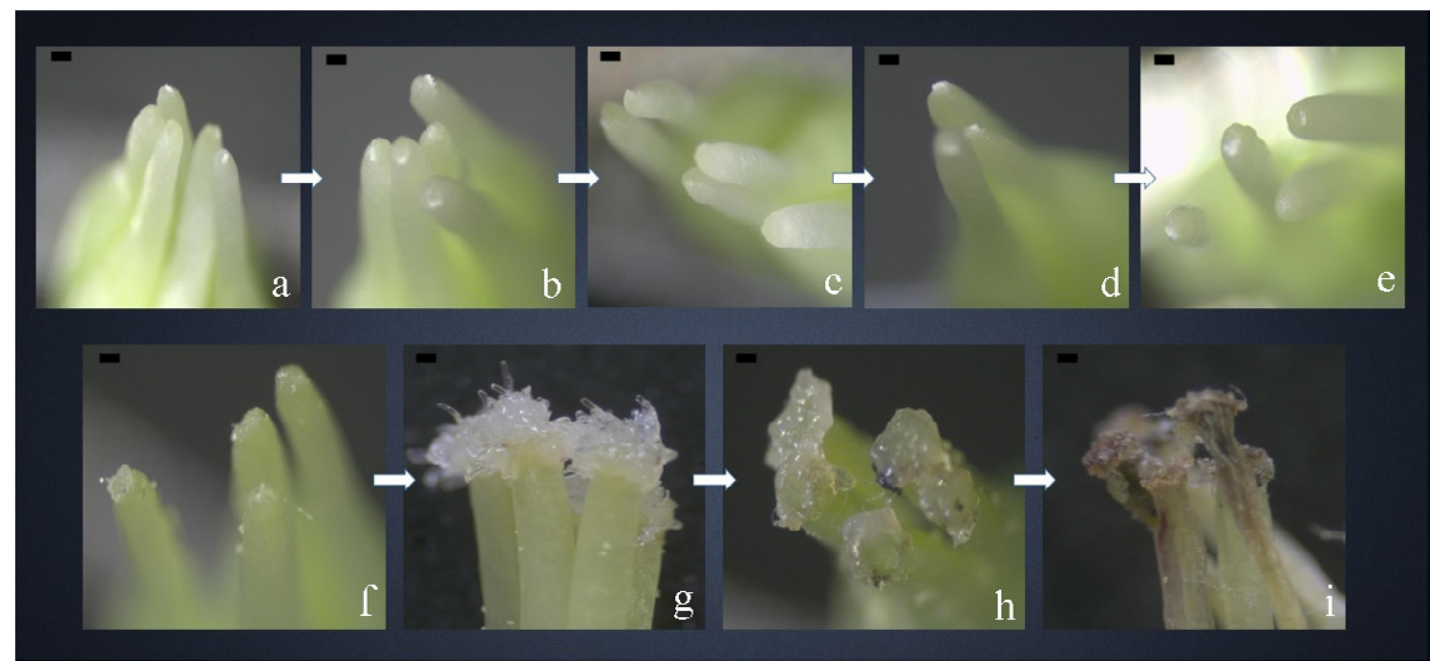

Figure 4. Development stages of the stigma of flowers belonging to Kalanchoë blossfeldiana. (a) Pistils are in compact form, stigma in smooth stage, no exudates appear. (b, c) Pistils start to dissociate and stigma is still in smooth stage, no exudates appear. (d, e) Stigmas start to form a small number of exudates and still in smooth stage. (f) Papilla cells of stigma slightly expand, small amount of exudates is present. (g) Papilla cells lose their arrangement and the exudates cover the whole stigma. (h) Papilla cells still expanded and the exudates are still visible. (i) Brown dried stigma and lack of exudates showing wilting. (Scale bars $=0.1 \mathrm{~mm}$ ).

In general hybridization studies, observing the morphology and physiology of stigma and determining the time it is receptive is extremely important for increasing the success of breeding. Similarly, pollen shedding periods are also very important as anthers may dehisce and start to give pollen at the beginning of stigma receptivity. In these cases, the time of the emasculation and pollination should be well arranged. Pollen viability and germination success is an important factor in breeding studies, which show the availability of male parent. Kalanchoë pollen viability can easily be tested with the TTC (2,3,5-triphenyl tetrazolium chloride) staining method, which enables breeders to know the dehydrogenase activity of pollens. The in vitro pollen germination can be done with agar in petri method with $15 \%$ sucrose $+1 \%$ agar medium in $25^{\circ} \mathrm{C}$. In the described germination conditions, pollen germination starts in the first 30 minutes and reaches the maximum in 3 hours.

The most effective method to distinguish between Kalanchö and Bryophyllum sections morphologically is to assess the inflorescence. The flowers are erect in the Kalanchö section, while they are pendent in the Bryophyllum section (Figure 5) (Descoings, 2006). In the Kalanchoë section, filaments are located in the middle or above the corolla. The calyx tube is usually shorter than the calyx lobes. In the Bryophyllum section, the filaments are located in the middle of the corolla and the calyx tube is longer than the calyx lobes. Moreover, while viviparous plantlets in the edge of the leaves are not found in the Kalanchoë section, they are found in the Bryophyllum section (Descoings, 2003). 


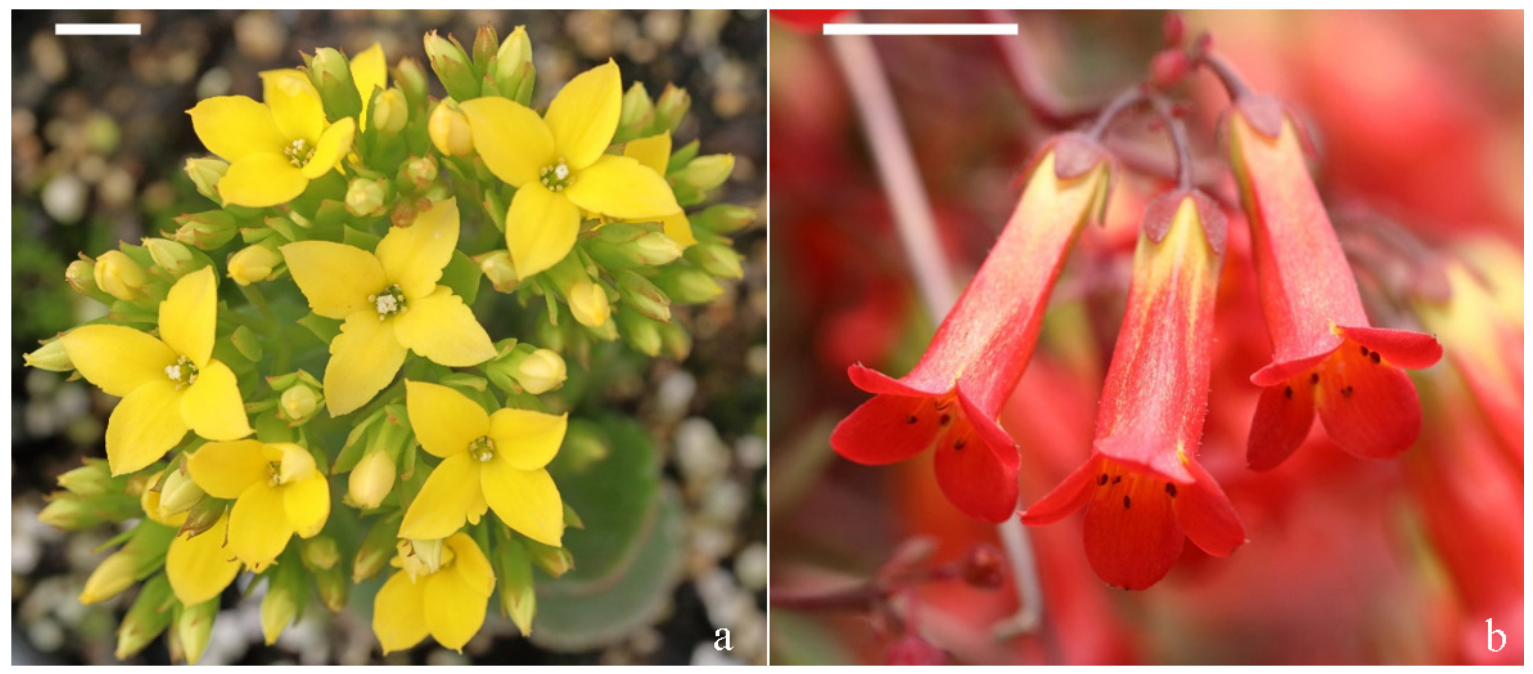

Figure 5. (a) Kalanchoë blossfeldiana derived cultivar (Section: Kalanchoë), (b) Kalanchoë manginii (Section: Bryophyllum). (Scale bars $=10 \mathrm{~mm})$.

There are some exceptions to the inflorescence in various species. The flowers are not only erect or pendent but they can also be seen as horizontal or nodding. Additionally, the flowers of some species can point in all directions depending on the maturity of the flower. For instance, the flowers belonging to $K$. alternans are pendent during the bud stage, horizontal or nodding during the full opening stage and pendent again after fully open. A large number of seeds are formed in the four carpels in the female organ. Kalanchoë seeds are ellipsoid, very small and striped (Figure 6) (Eggli, 2003). However, research on Kalanchoë seeds is limited.

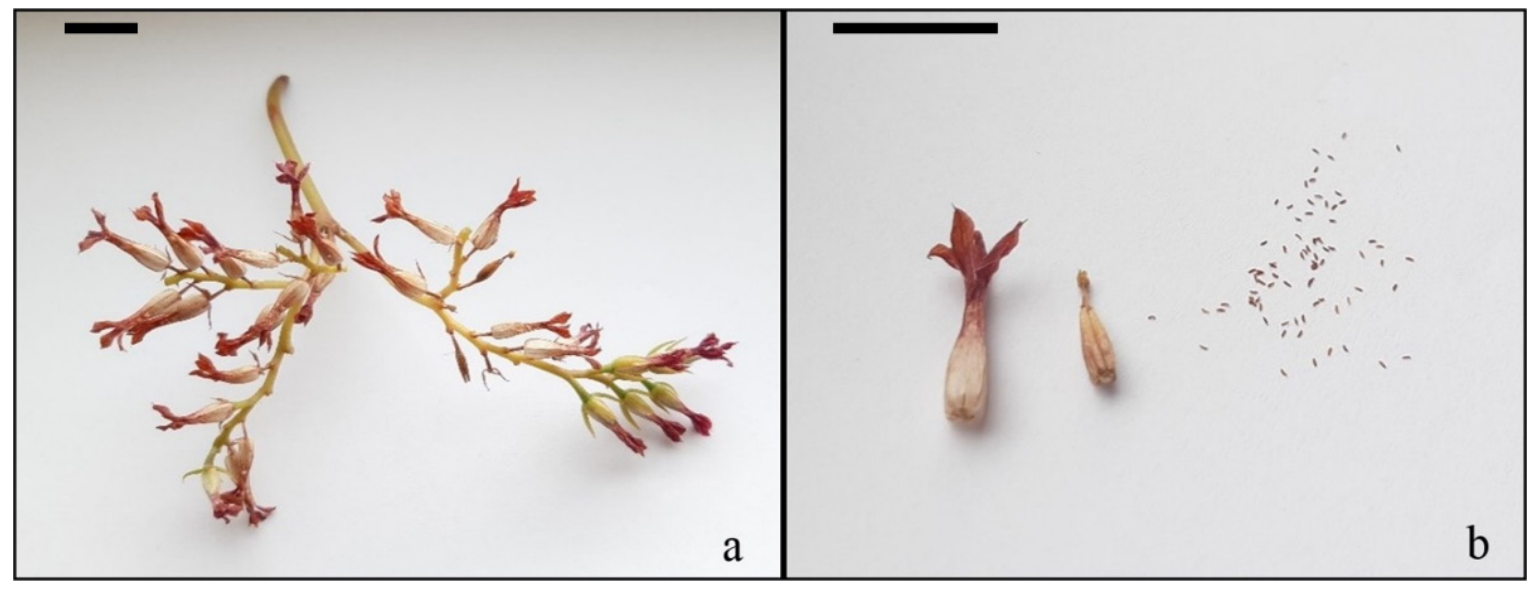

Figure 6. Kalanchoë blossfeldiana inflorescence and seeds, (a) inflorescence with including dried carpels, and (b) individual carpels with mature seeds removed. (Scale bar $=10 \mathrm{~mm})$.

Some of the species belonging to the Kalanchoe genus are short-day plants, while others are long-shortday plants. K. blossfeldiana, the most important species in Kalanchoë section, is a short-day plant. Some of the species belonging to the Bryophyllum section are longshort day plants and they first need long days and then short days for flowering (Zeevaart, 1985). K. blossfeldiana species bloom between 12-20 weeks after planting with 3.5-6 weeks' vegetative period and 8-12 weeks of short-day treatment in commercial cultivation (Slijkerman, 2021). Flowering time varies according to cultivars. Although the critical day length of K. blossfeldiana species is 12.5-13 hours, short-day treatment (darkening) is performed for 14 hours in commercial production (Jepsen and Christensen, 2010). The light demand of each species is different in the
Kalanchoë genus (Currey and Erwin, 2011) and flowering can also respond to different light quality and intensity of night interruption light (NIL) (Kang et al., 2019). For Kalanchoë, temperature and light quality during the day are also important factors affecting flowering (Mackenzie et al., 2018). Moreover, plant growth regulators, such as gibberellin; $\mathrm{GA}_{3}$, can accelerate or boost flowering in $K$. longiflora, $K$. sexangularis, $K$. nyikae, $K$. marnieriana, $K$. longiflora, and $K$. $\times$ richaudii and $K$. pinnata (Chang and Huang, 2018). It has been shown that the regulation of key flowering timing genes is possible based on the conserved gene structure and highly conserved derived proteins of mother of FT and TFL1-like (MFT), flowernng locus T-like (FT-like), and terminal flower1-like (TFL1like) (Mackenzie et al., 2019). Therefore, further flowering 
studies in Kalanchoë could benefit from including gene expression analysis and in-depth knowledge in flowering could be achieved by investigating the PEBP gene family.

It has been reported that birds and insects in nature are effective in the pollination of the Kalanchoë genus (Smith et al., 2019). Flowers of Kalanchoë secrete nectar from the membrane under the carpels (Hickey and King, 1988). The Kalanchoë genus usually includes species that are selfpollinating and partly self-pollinating (Herrera and Nassar, 2009). Seed viability is low in species with self-pollination. This is thought to be due to the dominance of allogamy (Gonzalez de Leon et al., 2016).

The basic chromosome number of the species belonging to the Kalanchoë genus is 17 (n) (K. aliciae, K. aromatica, $K$. blossfeldiana, $K$. crenata, $K$. daigremontiana, $K$. fedtschenkoi, $K$. gastonis-bonnieri, $K$. globulifera, $K$. laxiflora, $K$. longiflora, $K$. marmorata, $K$. miniata, $K$. peltatai, $K$. prolifera, $K$. rotundifolia, $K$. scandens, $K$. tomentosa, K. velutina, $K$. waldheimi). However, there are species with 18 (n) (K. beharensis, K. hildebrandti, and 20 (n) (K. pinnata, K. uniflora) chromosomes. K. blossfeldiana is diploid $(2 \mathrm{n}=34)$ in its natural environment, while almost all commercial cultivars are tetraploid $(2 n=4 x=68)$. Van Voorst and Arends (1982) reported that there are cultivars with chromosome number $2 \mathrm{n}=72$ (K. blossfeldiana 'Christine', K. blossfeldiana 'Solferinopurper'), 84 ( $K$. blossfeldiana 'Montezuma' and 96 ( $K$. blossfeldiana 'Ariake'). It has been reported that ploidy level and chromosome number do not affect success in hybridization between species in Kalanchoë (Izumikawa et al., 2007; Izumikawa et al., 2008; Kuligowska et al., 2015a).

\section{Breeding Purposes and Methods}

In the breeding of ornamental plants; flower and leaf characteristics (color, size, number of petals, shape, etc.), resistance to biotic and abiotic stress conditions, yield, suitability for transportation, propagation ability, vase life, flowering period are taken into consideration (Dai et al., 2019; Su et al., 2019; Van Huylenbroeck, 2020). Since the Kalanchö genus is mainly used as a potted ornamental plant, most of its breeding studies focused on indoor use. However, the increase in demand for its use as a cut flower (especially in EU countries) in recent years has started to encourage breeders to develop cultivars for this novelty purpose.

The primary goal in the development of potted cultivars is to improve the morphological characteristics of the plant. The main targets of the breeding for indoor areas are flower color, flower size, number of petals per flower, number of flowers per plant, duration of flowering, branching type, compactness, leaf size and shape. When commercial cultivar catalogs of companies are examined, it is seen that response time to photoperiod is also an important breeding criterion.

In recent years, double-colored Kalanchö̈ cultivars have also been developed and presented to the market. In addition to the flower color, flower size is also an important characteristic, and the diameter of the flower can reach up to $2 \mathrm{~cm}$ in double-flowered cultivars and $3 \mathrm{~cm}$ for cut flower cultivars (Slijkerman, 2021). Potted Kalanchoë cultivars are divided into two as single and double cultivars according to flower types. While the number of petals is four in single-flowered cultivars, it varies between 15 and 35 in doubled-flowered cultivars (Figure 7). The flowering period is another important characteristic and this period is required to be at least six weeks in commercial cultivars (Queen Flowers, 2021). The flowering period varies depending on environmental conditions. The number of flowers per plant in Kalanchoë varies between 100 and 350 (Jepsen and Christensen, 2010).
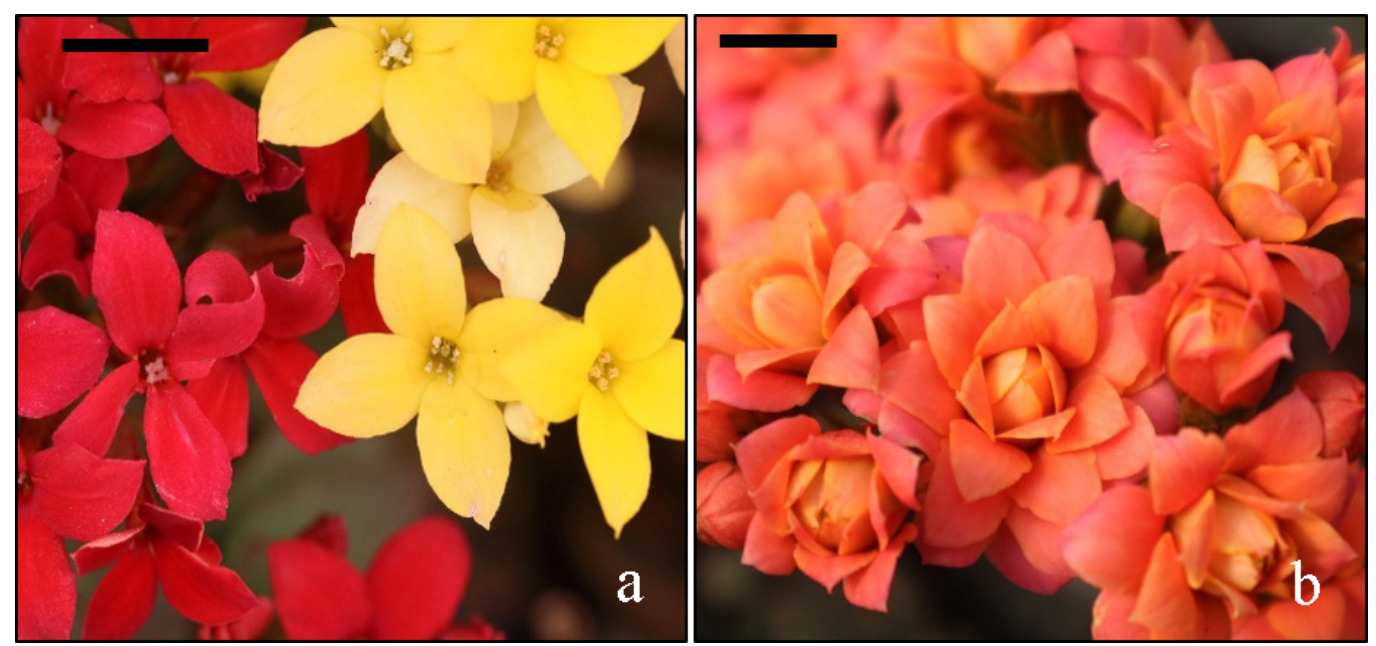

Figure 7. Variation in petal numbers of Kalanchoë derived cultivars (a) single petal and (b) double flowered. $($ Scale bars $=10 \mathrm{~mm})$. 
As with all other potted plants, the compact structure is among the important characteristic for Kalanchoë. Plant growth regulators are used in Kalanchoë cultivation to keep the plants in a compact structure and to ensure height control. However, many compounds were banned by regulating agencies, e.g., the European Union, the U.S. Environmental Protection Agency, the Chinese Ministry of Agriculture, Brazilian Health Regulatory Agency (ANVISA), and novel, less hazardous alternatives are needed. Abiotic biofriendly practices, e.g. brushing / shaking of plants, coldmorning treatment, light control, have can be applied in ornamental plant production to control growth (Bergstrand, 2017) but in some countries, growers are being pressured to reduce chemical use. Recently, a photoselective film was developed that specifically reduces the transmission of farred light [(FR. Nevertheless, these methods stop working and the plant resumes its normal growth once the treatment is interrupted, i.e. in the consumers' house and during transportation. On the other hand, it is possible to address compact growth from a genetic perspective, thus creating plants that genetically display reduced growth. Stable compact phenotypes have been achieved for Kalanchö̈ using Rhizobium rhizogenes (syn: Agrobacterium rhizogenes), (Christensen et al., 2008) (see also section 6.2) Commercial companies divide the flower sizes of plants in their catalogs into five groups as small, mediumsmall, medium, medium-large and large (Dümmen Orange, 2021). The development of characteristics such as glossy leaves, leaf size, and different leaf shapes are among the main breeding goals. According to the Community Plant Variety Office (CPVO, 2021), there are 1584 cultivars of Kalanchoë that have been developed and registered to date.

For cut flower cultivars; flower characteristics (color, shape, size, number of petals per flower), number of flowers per plant, flower stem length, photoperiodic response, yield, suitability for transportation and vase life are the most important characteristics (Mibus, 2018). In cut flower cultivars, the vase life of the flowers is desired to be three weeks or more. Moreover, ethylene tolerance is also an important criterion, and there are commercial cultivars with high ethylene tolerance on the market.

For breeding studies, it is necessary to create a gene pool containing starting materials with a large variation in the direction of targets. Variation can be provided in two ways. The first is the natural variation provided by the combination of materials obtained from different sources. The other is a variation created by hybridization, mutation, and genetic modification. Generating the gene pool from starting materials with a large variation for breeding purposes increases the success. The choice of breeding method depends largely on the breeding technique of the species and the propagation methods of the material. Other factors, which are effective in determining the strategy, are the inheritance degree of the characteristics, the number of genes that affect inheritance and the effect of environmental factors. All these factors are effective in determining breeding stages and selection methods.

\section{Conventional Breeding}

\section{Pollination}

In Kalanchoë flowers, the male organs mature before the female organs (protandry), thus emasculation (removal of the male organs and a part of corolla) should be done before the flowers open and most likely best performed at the bud stage (Figure 8 ). In the pollination process, a brush can be used, or the male organs with fertile pollen on their anthers can be excised and used (Figure 9).
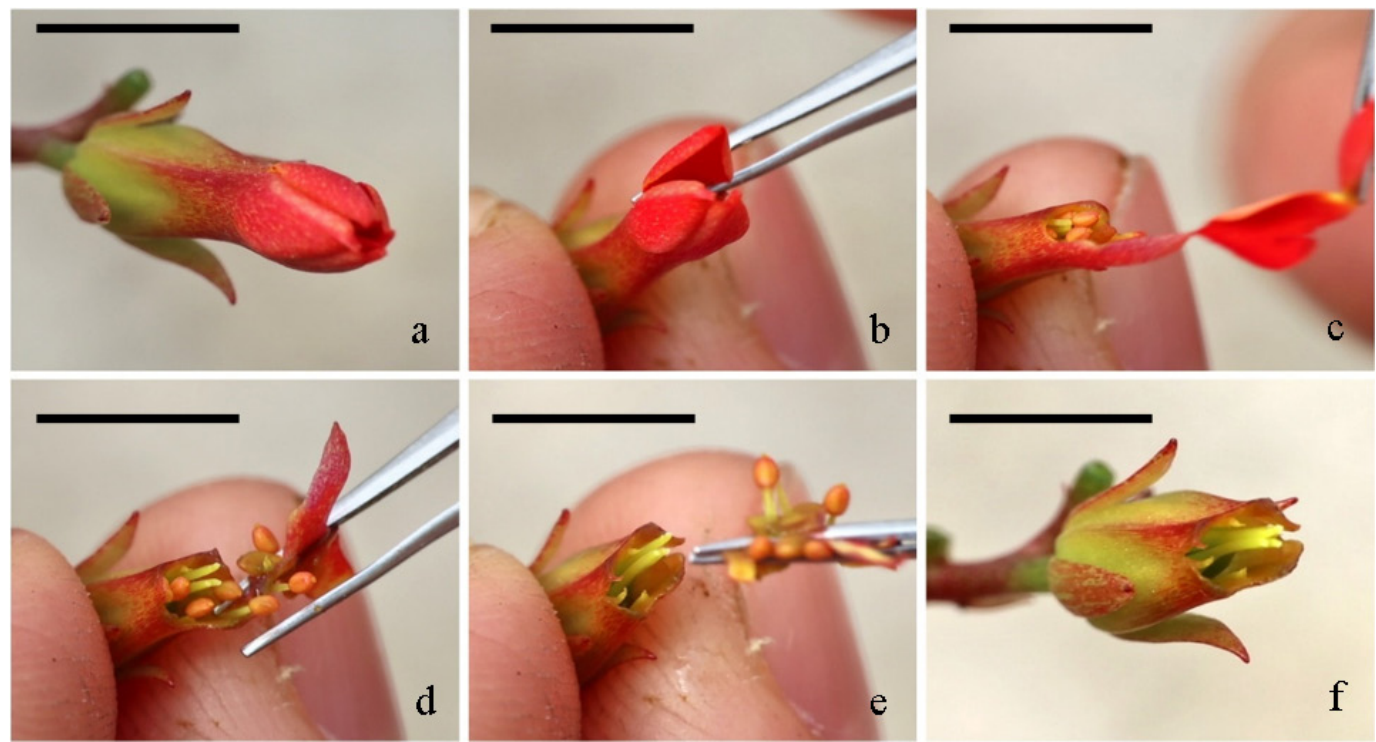

Figure 8. Emasculation process of Kalanchoë flower. (a) Intact flower, (b) opening petals with a tweezer, (c) removing the top part of the petals, (d) initiating stamen removal, (e) completing the removal of stamen and (f) fully emasculated flower. (Scale bars $=10 \mathrm{~mm}$ ). 

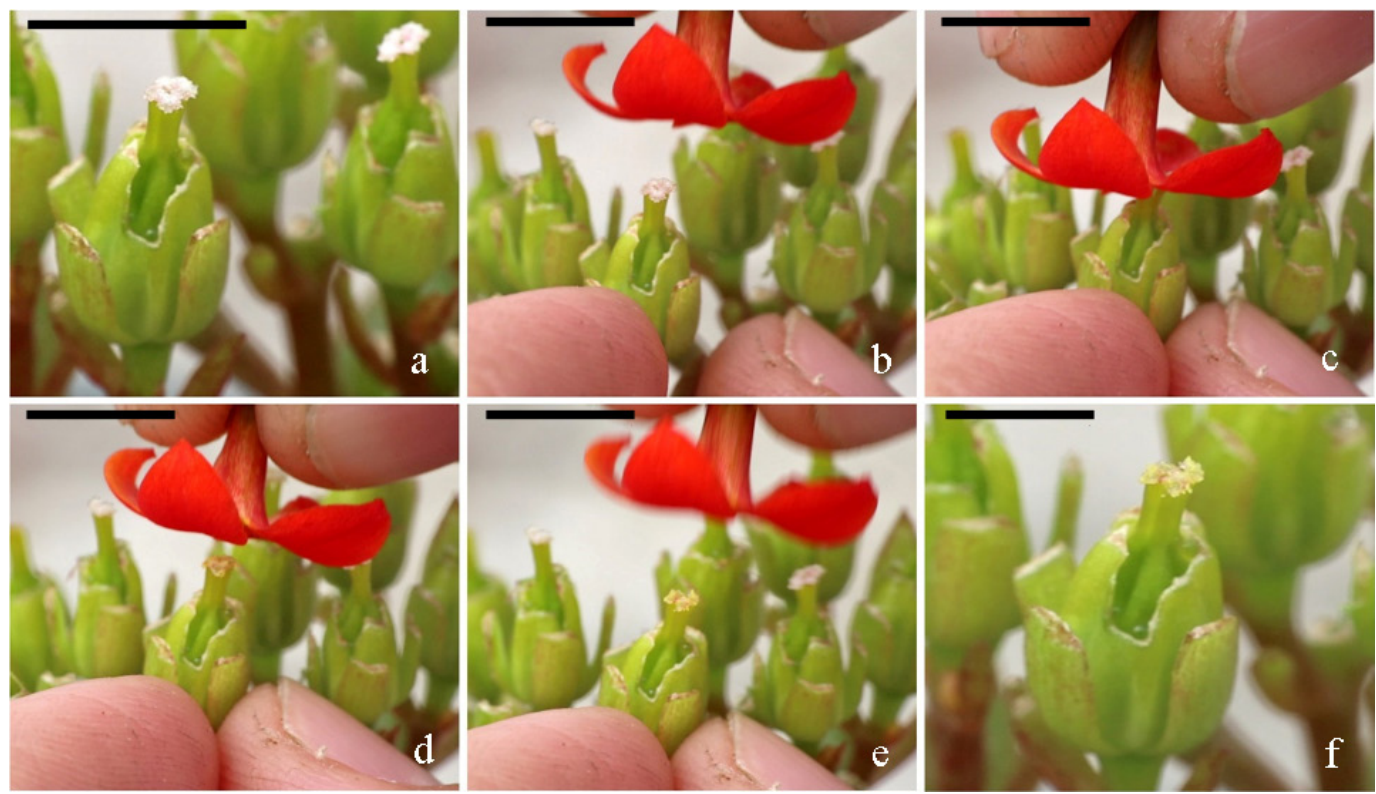

Figure 9. Pollination process of Kalanchoë flower. (a) Emasculated flower is (b) brought in contact with a male parental flower (c-e) several times to ensure the (f) pollination was completed. (Scale bars $=10 \mathrm{~mm}$ ).

\section{Interspecific Hybridization}

Interspecific hybridization plays an important role in ornamental breeding. Interspecific hybridization is a method frequently used in different ornamental plant species from past to present. The success of interspecific hybridization and the barriers encountered while achieving this success are the subject of research by breeders and researchers. For many ornamental plants interspecific hybridization has been pursued such as Begonia (Siregar, 2016), Delphinium (Cheng et al., 2020), Dianthus (Dewanti et al., 2019), Eustoma (Barba-Gonzalez et al., 2017), Gentiana (Takamura et al., 2019), Hibiscus (Kuligowska et al., 2016a), Iris (Lian et al., 2016), Nymphaea (Sun et al., 2018), Phalaenopsis (Rungruchkanont and Promchot, 2016), Rosa (Farooq et al., 2016), Tagetes (He et al., 2016), Tulipa (Xing et al., 2020), Vibirnum (Xie et al., 2017) and Viola (Żabicka et al., 2020).

For Kalanchoë, hybridization between both species and sections (Kalanchö̈ and Bryophyllum) have been made and new cultivars were developed as a result of these experiments. Today, interspecific hybridization and biotechnological methods are widely used in the development of new Kalanchö cultivars. Wild species are important gene sources for breeding studies with their attractive leaf and flower shapes, colors, branching structures, compactness, a high number of flowers, and high petal numbers. It is possible to obtain highly interesting hybrids with different characteristics in terms of breeding, especially when cultivated forms are used as maternal parents and wild species are used as paternal parents. There are different wild species that can be hybridized with the available $K$. blossfeldiana cultivars (Izumikawa et al., 2007). From the past to the present, a large number of hybridizations have been made both between sections and within sections and hybrids have been obtained. $K$. aromatica, $K$. beauverdii, $K$. bentii, $K$. blossfeldiana, $K$. citrina, $K$. daigremontiana, $K$. delagoensis, $K$. farinacea, $K$. garambiensis, $K$. glaucescens, $K$. gracilipes, $K$. grandiflora, $K$. laciniata, $K$. lanceolata, $K$. lateritia, $K$. laxiflora, $K$. manginii, $K$. marnieriana, $K$. miniata, $K$. nyikae, $K$. porphyrocalyx, $K$. pubescens, $K$. pumila, $K$. rosei, $K$. rotundifolia, and $K$. spathulata species were used for interspecific and intersectional hybridization and successful results were obtained (Mackenzie et al., 2018).

There are some factors that affect and restrict success in interspecific hybridization. These factors are divided into two as pre-fertilization and post-fertilization barriers. Pre-fertilization barriers are caused by factors such as lack of receptivity of stigma during pollination, lack of pollen, pollen not germinating on the stigma, the pollen tube not reaching the ovary or disappearing before it reaches the ovary, the pollen tube is abnormally developed in the pollinated parent. Post-fertilization barriers are caused by factors such as the inability of the zygote to divide or develop, the underdevelopment or the abnormal development of the embryo and/or the endosperm, etc. (Kuligowska et al., 2015a). The germination ability of seeds obtained from hybridization between species of Kalanchoë may be very low or nonexistent. This problem, which appears as a postfertilization barrier, is most likely related to the endosperm. The endosperm may not have developed or formed at all. This situation causes problems in the feeding of the embryo. Barriers caused by interspecific hybridization can be overcome with embryo rescue techniques (embryo, ovule, and ovary).

\section{Mutation Breeding}

Mutations cause artificial changes to an existing variety. The material obtained after mutation breeding can be used as a starting material in breeding studies or can 
be considered as a new cultivar. With mutation breeding, the longtime requirement in conventional hybridization studies may be eliminated. However, transferring the characteristics obtained by mutation breeding to nextgeneration clones may be difficult. The use of mutation breeding in ornamental plants is generally in the form of artificially and randomly induced changes in the leaves or flowers of commercial cultivars using physical such as X-rays (Sawada, 2019; Li et al., 2021) or gamma rays (Patil et al., 2017; Datta, 2020) and chemical mutagens such as ethyl or methyl methane sulfonate (Follmann et al., 2016; Mendoza-Gomez, 2020; Purente et al., 2020), diethyl sulfate (El-Nashar and Asrar, 2016) or sodium azide (Wannajindaporn et al., 2016; Mostafa et al., 2019). The most important issue in mutation breeding is to obtain a new plant from the mutated plant part and to make mass production (Ibrahim et al., 2018; Hernandez-Munoz et al., 2019). It has been scientifically proven before that the ability of the Kalanchoë species to form shoots with the adventitious bud method is high and that individuals flowing mutation can be successfully produced in this way. Mutations that caused changes in the flower and leaves, plant structure and other morphological characteristics of the Kalanchoë plant have been obtained with physical mutagens (Broertjes and Leffring, 1972). Moreover, mutagenic variation in Kalanchoë has previously been obtained by chemical mutagens (Krupa-Malkiewicz, 2010). Ethyl methane sulfonate, methyl methane sulfonate and, diethyl sulfate (DES) were used as chemical mutagens to create mutagenic variation. Moreover, 2.0 mM DES was found to be the most effective chemical mutagen in the study (Krupa-Malkiewicz, 2010). Four mutant cultivars have been developed and registered until today with mutation breeding in Kalanchoë (Table 1) (IAEA, 2021). However, mutation breeding is not a common method in Kalanchö̈, and the hybridization method is used more.

Table 1. Mutant cultivars developed in Kalanchö̈ (IAEA, 2021)

\begin{tabular}{|c|c|c|c|c|c|}
\hline $\begin{array}{l}\text { Cultivar } \\
\text { Name }\end{array}$ & Country & Year & Species name & Method & Developed Characteristics \\
\hline Flores & The Netherlands & 1985 & Kalanchoë sp. & X-rays (10-30 Gy) & Compact plant \\
\hline Lombok & The Netherlands & 1985 & Kalanchoë sp. & X-rays (10-30 Gy) & $\begin{array}{c}\text { Pure red flower color and rather } \\
\text { upright growth habit }\end{array}$ \\
\hline Sumba & The Netherlands & 1985 & Kalanchoё sp. & X-rays (10-30 Gy) & Strongly branching growth habit \\
\hline $\begin{array}{l}\text { Harvest } \\
\text { Moon }\end{array}$ & Japan & 1996 & Kalanchoё sp. & Gamma rays & Improved flower shape \\
\hline
\end{tabular}

\section{Selection}

Kalanchö is a commercially propagated vegetative plant. For this reason, the clonal selection method is used in the plant selection stage after hybridization. Plants produced vegetatively from a single plant are called "clone". Clones are somatic tissue fragments and plant tissues formed with apomixis (asexual seed formation without fertilization). All plants in the clone genetically have the same characteristics and carry the genotype of the parent plant. Clonal selection is a selection method frequently used in ornamental plants. Many ornamental plants traded in the world have been developed by this selection method. In cultivar development studies of the species, selections are made by looking at criteria such as the time from planting to flowering, flower stem length, number of flowers per plant, number of petals per flower, color, flower size, leaf characteristics, fragrance, resistance to biotic and abiotic stress conditions, vase life, market demands, as well as yield and other evaluations. These criteria differ according to the characteristics of the species. Whichever selection method is used, the success of selection depends on the correct observation of the characters to be considered in selection. In vegetative growing plants, the clonal selection method is used very successfully, especially in mixed populations. With this method, superior clones in the population can be easily selected, especially according to their morphological characteristics. Success in selection depends on genetic variation in the population. The larger the population, the more likely it is to find individuals with desired characteristics (Grüneberg et al., 2009). The purpose of clonal selection is to determine the most superior clones suitable for breeding purposes by making use of the existing differences. In order to increase the variation, hybridization studies are carried out, chemical or physical mutagens are used (refer to sections above, Section 6.1., Mutation Breeding). The variability of the breeding material is greatly increased by hybridization. In the time following the hybridization, the selection of genotypes suitable for the purpose is made. Plants selected appropriately for the purpose are clonally propagated and individuals who may have superior characteristics are determined by the selection.

The steps for the clone selection method can be listed as follows:

1. In the first stage, the genotypes obtained by hybridization are planted and their performance is evaluated. Morphological characterization and selection studies are carried out at this stage.

2. Selected plants are propagated by cuttings and planted, thus, A-clones (The first selected clone group to have the desired characters) are obtained. Afterwards, clones are 
propagated after selecting plants suitable for breeding purposes with a performance test and morphological observations, and thus B-clones are obtained. According to field observations, among the A-Clones, those that are not suitable for breeding purposes are eliminated.

3. Plants propagated as B-clone are planted in rows. B-clones are subjected to more detailed tests by examining their morphological characteristics as well as yield, quality and disease observations. Among the B-clones, superior clones are selected and these are propagated to generate C-clones (candidate cultivars).

4. Data obtained from C-clones are evaluated by statistical analysis. After analysis results, adaptation and stability tests, one or more clones are registered as a cultivar.

\section{Biotechnological Methods}

With conventional plant breeding methods, the process is often lengthy and sometimes it is not possible to achieve the desired variation in characteristics such as flower color and form, fragrance, plant height and vigor, leaf form, resistance to diseases and pests. In order to obtain the desired characters, it is necessary to do more than one backcrossing, which extends the breeding process. Furthermore, incompatibility problems may be encountered in interspecific hybridization (Kuang et al., 2021). New developments in the field of plant biotechnology have made it possible to overcome problems that cannot be overcome with the classical breeding method. Some of these methods are used together with classical breeding while some are used alone.

\section{Embryo rescue method and protoplast isolation}

The basis of the embryo rescue technique is based on the development of embryos in a tissue culture medium. Embryo rescue is done in three different ways. These are ovary, ovule and embryo culture techniques. In practice, mature and immature embryos are cultured. It is more difficult to isolate the embryo in immature embryo culture (Lafon-Placette and Köhler, 2016). Embryo isolation is difficult, especially in plants with small seeds. In this situation, ovule and ovary cultures are used (Kuligowska, 2016b; Bridgen et al., 2018; Pramanik et al., 2021). Embryo rescue methods are frequently used in interspecific hybridization in ornamental plants. Ovule culture is especially used in Kalanchoë (Izumikawa et al., 2008). Kuligowska et al. (2015b) made reciprocal hybridization in different Kalanchoë species and obtained offspring. Almost all hybrids showed the moderate distance to both maternal and paternal parents. Abnormal growths, undeveloped endosperms and embryos were found in the obtained seeds. At the end of the study, it was stated that the embryo rescue method was needed to increase the success for obtaining individuals as a result of interspecific hybridization. Izumikawa et al. (2008) conducted a reciprocal intersectional hybridization between $K$. spathulata and $K$. laxiflora. When K. spathulata was used as maternal parent, 39 out of 80 hybrids (49\%) showed a moderate distance to both $K$. spathulata and $K$. laxiflora. In the opposite combination, that is hybridization in which $K$. laxiflora is the maternal parent, hybrids were not obtained. At the end of the study, it was stated that the embryo rescue method was needed to obtain hybrids as a result of hybridization. Izumikawa et al. (2007) made both interspecific and intersectional hybridization in another study and obtained successful results. Combination of $K$. blossfeldiana with $K$. citriana, $K$. farinacea, $K$. garambiensis, $K$. nyikae, $K$. pumila, K. spathulata as interspecific hybridization, and combination of $K$. blossfeldiana with $K$. daigremontiana, $K$. laxiflora, and $K$. pubescens as intersectional hybridization was conducted reciprocally. The aim of the study was to provide genetic variation to Kalanchoë for breeding as in almost all other studies. The ovule rescue in Kalanchoë is similar to the techniques applied in other plants. Twothree weeks after hybridization, the ovaries are collected while swollen and sterilized under laboratory conditions. Then, the ovules in the sterilized ovaries are excised and cultured in an embryo rescue medium. Embryo rescue has been successful with this method (Izumikawa et al., 2007). Additionally, protoplast isolation can be applied to create new variation in respect to developing somatic hybrids (individuals that are obtained through the fusion of somatic protoplasts of two different plant species/cultivars). This has been applied in twelve Kalanchoë accessions, belonging to nine species and $K$. blossfeldiana 'Charming Red Meadow' was found to yield the highest number of protoplasts (Cui et al., 2019). Hereby, there is a potential to facilitate the use of Kalanchö in somatic hybridizations breeding programs.

\section{Polyploidy}

Polyploidy can increase the size of plant parts such as flowers and leaves in ornamental plant species. Polyploidy can occur spontaneously by natural mutation, or it can be created artificially by using chemical mutagens or by somatic mutations that occur under in vitro regeneration (Eeckhaut et al., 2018). Polyploidy is a widely used method in ornamental plant breeding. A plethora of commercial ornamental cultivars in many species are polyploid (Sattler et al., 2016; Jeloudar et al., 2019; Niazian and Nalousi, 2020). Moreover, Aida and Shibata (2002) indicated that obtaining regenerants at different ploidy levels by using the leaf segments of the K. blossfeldiana 'Tetra Vulcan' cultivar with $4 \mathrm{x}$ chromosome structure and reported that the method was extremely applicable for breeding studies. In another study, the chromosomes of the individual obtained from the hybridization between $K$. spathulata and $K$. laxiflora were doubled by in vitro regeneration and pollen productivity was restored to some extent (Izumikawa et al., 2007). In another study by Kuang et al. (2021), interspecific hybridization was conducted in $K$. blossfeldiana, K. garambiensis, $K$. nyikae, K. lobata, $K$. velutina, $K$. longiflora, and $K$. sexangularis. In the study, colchicine treatments on apical buds were conducted and ploidy levels were doubled successfully to overcome meiotic abnormalities. 


\section{Genetic transformation}

Successful results can be obtained with the genetic transformation of ornamental plants. Several genetic transformation studies in the Kalanchoë genus have been carried out. In a previous study, the transfer of $\beta$-glucuronidase gene (GUS) to $K$. blossfeldiana 'Tetra Vulcan' via Agrobacterium tumefaciens was successful (Aida and Shibata, 1996). In another study conducted by Thirukkumaran et al. (2009), it was stated that the ipt (isopentenyl transferase) gene could be a selectable marker for the production of marker-free transgenic $K$. blossfeldiana plants. Sanikhani et al. (2009) made a genetic transformation into commercial cultivars $K$. blossfeldiana 'Celine' by Agrobacterium tumefaciens containing pBEO210 plasmid. The mutated etr $1-1$ ethylene receptor gene obtained from Arabidopsis thaliana was transferred to the plant under the control of the fbpl-promoter obtained from petunia. As a result of the study, sensitivity to ethylene was reduced and transgenic plants with longer flowering were obtained. In another study, male-sterile plants that provide many advantages such as prolonging the flowering time of $K$. blossfeldiana and eliminating pollen allergy were obtained by genetic transformation through A. tumefaciens (García-Sogo et al., 2010). In another study, the SHORT INTERNODES $(S H I)$ gene, previously obtained from Arabidopsis thaliana and causes a defect in gibberellic acid (GA) perception, was overexpressed in eight different commercial Kalanchoë cultivars via $A$. tumefaciens and compact transgenic plants were successfully obtained. In contrast to the phenotype observed by overexpression in Arabidopsis, late-flowering was only observed in few cultivars, furthermore, this situation was eliminated by exogenous application of GA in minute concentrations and did not cause a change in the compact characteristic of the plant (Lütken et al., 2010). Additionally, it has been found that tissue specific promoters as $d B I$, which is a deletion BOX-I from the Pisum PLAl promoter, reduced the stem length two-fold without affecting the number of internodes in transgenic Kalanchoë containing Nicotiana GA2ox (Gargul et al., 2017). Furthermore, compact plant growth was also obtained by modulation of the homeotic $K N O X$ genes in $K$. blossfeldiana 'Molly' (Lütken et al., 2011). In another study, Gargul et al. (2015) transferred the MKS 1 gene obtained from the Arabidopsis thaliana plant to K. blossfeldiana via Agrobacterium and obtained compact transgenic plants with flowering delayed about 6 to 11 days compared to wild type.

With the use of root oncogenic loci ( $r o l)$ genes in potted plants, as a result of genetic transformation, plants with compact growth, short internodes, reduced apical dominance characteristic and increased lateral shoot formation can be obtained (Lütken et al., 2012a; Rangslang et al., 2018; Desmet et al., 2020). As a result, genetic transformation using agropine-type $R$. rhizogenes for $K$. blossfeldiana 'Molly', compact plants with short internodes, high number of roots and branches were obtained. However, besides these beneficial characteristics, negative morphological features such as smaller flower size and curled leaves were also observed (Christensen et al., 2008). In later studies, the T1 line 331 obtained from 'Molly' by $R$. rhizogenes was hybridized with $K$. blossfeldiana 'Sarah', and it was observed that the rol-genes in the T1 line were transferred to F1 hybrid plants and that hybrid plants also exhibited the compactness characteristics. Later, F1 plants were inbred and it was found that the same correlation between the presence of rol-genes and compactness continued in the obtained F2 plants (Lütken et al., 2012b). Moreover, the study of individual rol genes and less characterized open reading frames from $R$. rhizogenes have very recently been shown to present higher ethylene tolerance in transgenic lines containing 35S::ORF14 (Favero et al., 2021).

\section{Conclusions}

Kalanchoë is an important ornamental potted plant with its high demand on the market with long-lasting flowers, fleshy leaves, low water requirement and easy maintenance. Because of the increasing interest in the plant, new cultivars with different characteristics in flower color, flower size, flower number, petal number, compactness, vigor, flower life and shape of leaves are frequently introduced to the market as a result of breeding studies. Conventional plant breeding used in the development of new and different cultivars can cause some difficulties for breeders in terms of time and convenience.

Several biotechnological methods have successfully been used to overcome these difficulties. The embryo rescue method is particularly effective in overcoming barriers before and after fertilization in interspecific and intersectional hybridization. Moreover, genetic transformation studies have been carried out for research purposes. Compact plants have been obtained using different strains of Agrobacterium. Biotechnological methods are used both as a supportive and stand-alone method in addition to conventional plant breeding. In the coming years, these studies are expected to increase in Kalanchoë, as in other ornamental plants.

\section{Author Contribution}

MUK: creating the idea, reviewing literature, writing the manuscript and taking photos for the manuscript; YYM: evaluation of the manuscript; ŞK: reviewing literature, writing flower morphology and pollination biology section; HL: reviewing literature, writing the manuscript, editing and revision of the manuscript; BTF: creating the idea, reviewing literature, writing the manuscript, editing and revision of the manuscript.

\section{References}

AIDA, R.; SHIBATA, M. Transformation of Kalanchoe blossfeldiana mediated by Agrobacterium tumefaciens and transgene silencing. Plant Science, v.121, n.2, p.175-185, 1996. https://doi.org/10.1016/S0168-9452(96)04524-4

AIDA,R.; SHIBATA,M.High Frequency of polyploidization in regenerated plants of Kalanchoe blossfeldiana cultivar 'Tetra Vulcan'. Plant Biotechnology, v.19, n.5, p.329-334, 2002. https://doi.org/10.5511/plantbiotechnology.19.329 
ALLORGE-BOITEAU, L. Madagascar centre de speciation et d'origine du genre Kalanchoe (Crassulaceae). Biogéographie de Madagascar, p.137-145, 1996.

BARBA-GONZALEZ, R.; TAPIA-CAMPOS, E.; LARABAÑUELOS, T.Y; CEPEDA-CORNEJO, V. Eustoma breeding, interspecific hybridization and cytogenetics. Acta Horticulturae, v.1167, p.197-203, 2017. https://doi. org/10.17660/ActaHortic.2017.1167.30

BERGSTRAND, K.J.I. Methods for growth regulation of greenhouse produced ornamental pot- and bedding plants - a current review. Folia Horticulturae, v.29, n.1, p.63-74, 2017. https://doi.org/10.1515/fhort-2017-0007

BOITEAU, P.; ALlORGE-BOITEAU, L. Kalanchoe (Crassulacées) de Madagascar: systématique, écophysiologie et phytochimie. Paris: KARTHALA Editions, 1995. 252p.

BRIDGEN, M.P.; VAN HOUTVEN, W.; EECKHAUT, T. Plant Tissue Culture Techniques for Breeding. In: VAN HUYLENBROECK, J. (eds). Ornamental Crops. Handbook of Plant Breeding. Cham: Springer, 2018. p.127144.

BROERTJES, C.; LEFFRING, L. Mutation breeding of Kalanchoë. Euphytica, v.21, n.3, p.415-423, 1972. https:// doi.org/10.1007/BF00039336

CHANG, M.Z.; HUANG, C.H. Effects of GA3 on promotion of flowering in Kalanchoe spp. Scientia Horticulturae, v.238, p.7-13, 2018. https://doi. org/10.1016/j.scienta.2018.04.001

CHENG, Y.; GUAN, W.; LI, F. Characterisation and evaluation of interspecific cross-incompatibility in two Delphinium species. Folia Horticulturae, v.32, n.2, p.111, 2020. https://doi.org/10.2478/fhort-2020-0027

CHERNETSKYY, M. Problems in nomenclature and systematics in the subfamily Kalanchoideae (Crassulaceae) over the years. Acta Agrobotanica, v.64, n.4, p.67-74, 2011. https://doi.org/10.5586/aa.2011.047

CHRISTENSEN, B.; SRISKANDARAJAH, S.; SEREK, M.; MÜLLER, R. Transformation of Kalanchoe blossfeldiana with rol-genes is useful in molecular breeding towards compact growth. Plant Cell Reports, v.27, n.9, p.1485-1495, 2008. https://doi.org/10.1007/s00299-0080575-0

CPVO. Kalanchoe Variety Database. 2021. Available at: $<$ https://vf.plantvarieties.eu/varieties $>$. Accessed on: Marc. $20^{\text {th }} 2021$.
CUI, J.; KULIGOWSKA MACKENZIE, K.; EECKHAUT, T.; MÜLLER, R.; LÜTKEN, H. Protoplast isolation and culture from Kalanchoë species: optimization of plant growth regulator concentration for efficient callus production. Plant Cell, Tissue and Organ Culture, v.138, n.2, p.287-297, 2019. https://doi.org/10.1007/s11240-019-01624-4

CURREY, C.J.; ERWIN, J.E. Photoperiodic flower induction of several Kalanchoe species and ornamental characteristics of the flowering species. Journal of the American Society for Horticultural Science, v.46, n.1, p.35-39, 2011. https://doi.org/10.21273/HORTSCI.46.1.35

DAI, S.; SONG, X.; DENG, C.; GAO, K.; LI, M.; MA, C.; ZHANG, M. Comprehensive approach and molecular tools for breeding and production of ornamental crops. Acta Horticulturae, v.1263, p.1-16, 2019. https://doi. org/10.17660/ActaHortic.2019.1263.1

DATTA, S.K. Induced mutations: technological advancement for development of new ornamental varieties. Nucleus, v.63, p.119-129, 2020. https://doi.org/10.1007/ s13237-020-00310-7

DESCOINGS, B. Kalanchoe. In: EGGLI, U. Illustrated handbook of succulent plants: Crassulaceae, 2003. p.143-181.

DESCOINGS, B. Le genre Kalanchoe, structure et définition. Journal de Botanique de la Société Botanique de France, v.33, p.3-28, 2006.

DESMET, S.; DHOOGHE, E.; DE KEYSER, E.; VAN HUYLENBROECK, J.; MÜLLER, R.; GEELEN, D.; LÜTKEN, H. Rhizogenic agrobacteria as an innovative tool for plant breeding: current achievements and limitations. Applied Microbiology and Biotechnology, v.104, n.6, p.2435-2451, 2020. https://doi.org/10.1007/s00253-020-10403-7

DEWANTI, M.; ROSTINI, N.; KARMANA, M.H. Phenotypic performance of six interspecific carnation genotypes obtained from hybridization of Dianthus caryophyllus "Liberty" x Dianthus chinensis "SK 11-1". Earth and Environmental Science, v.308, n.1, 2019. https://doi.org/10.1088/1755-1315/308/1/012063

DÜMMEN ORANGE. Kalanchoe Catalogue. 2021. Available at: <https://na.dummenorange.com/app/ pdfcatalogs/detail.web?catalogId $=119>$. Accessed on: 30 April 2021.

EECKHAUT, T.; VAN DER VEKEN, J.; DHOOGHE, E.; LEUS, L.; VAN LAERE, K.; VAN HUYLENBROECK, J. Ploidybreedinginornamentals. In:VANHUYLENBROECK, J. (eds) Ornamental Crops. Handbook of Plant Breeding. Cham: Springer, 2018. P.145-173 
EGGLI, U. Crassulaceae. Illustrated Handbook of Succulent Plants: Crassulaceae. Berlin Heidelberg: Springer, 2003. p.374.

EL-NASHAR, Y.I.; ASRAR, A.A. Phenotypic and biochemical profile changes in calendula (Calendula officinalis L.) plants treated with two chemical mutagenesis. Genetics and Molecular Research, v.15, n.2, 2016. https://doi.org/10.4238/gmr.15028071.

FAROOQ, A.; LEI, S.; NADEEM, M.; ASIF, M.; AKHTAR, G.; BUTT, S.J. Cross compatibility in various scented rosa species breeding. Pakistan Journal of Agricultural Sciences, v.53, n.4, p.863-869, 2016. https:// doi.org/10.21162/PAKJAS/16.1817

FAVERO, B.T.; TAN, Y.; LIN, Y.; HANSEN, H.B.; SHADMANI, N.; XU, J.; HE, J.; MÜLLER, R.; ALMEIDA, A.; LÜTKEN, H. Transgenic Kalanchoë blossfeldiana, containing individual rol genes and open reading frames under 35 s promoter, exhibit compact habit, reduced plant growth, and altered ethylene tolerance in flowers. Frontiers in Plant Science, v.12, p.840, 2021. https://doi.org/10.3389/fpls.2021.672023

FLORAL DAILY. "Interest for kalanchoë cutflowers goes beyond Europe." 2016. Available at: <https://www. floraldaily.com/article/9007493/interest-for-kalanchoecutflowers-goes-beyond-europe/ $>$. Accessed on: Jan $12^{\text {th }}$ 2021.

FOLLMANN, D.N.; SOUZA, V.Q.; NARDINO, M.; CARVALHO, I.R.; SCHMIDT, D.; MEIRA, D.; MEIER, C.; FERRARI, M.; de PELEGRIN, A.J.; SZARESKI, V.J. Induction of genetic variability and plant development in palisade grass evaluated in M2 mutants. African Journal of Agricultural Research, v.11, n.34, p.3210-3216, 2016. https://doi.org/10.5897/AJAR2016.11041

GARCÍA-SOGO, B.; PINEDA, B.; CASTELBLANQUE, L.; ANTÓN, T.; MEDINA, M.; ROQUE, E.; TORRESI, C.; BELTRÁN, J.P.; MORENO, V.; CAÑAS, L.A. Efficient transformation of Kalanchoe blossfeldiana and production of male-sterile plants by engineered anther ablation. Plant Cell Reports, v.29, n.1, p.61-77, 2010. https://doi. org/10.1007/s00299-009-0798-8

GARGUL, J.M.; MIBUS, H.; SEREK, M. Manipulation of MKS1 gene expression affects Kalanchoë blossfeldiana and Petunia hybrida phenotypes. Plant Biotechnology Journal, v.13, n.1, p.51-61, 2015. https://doi.org/10.1111/ pbi. 12234

GARGUL, J.M.; MIBUS, H.; SEREK, M. Characterization of transgenic Kalanchoë and Petunia with organ-specific expression of $G U S$ or $G A_{2}$ ox genes led by the deletion BOX-I version $(d B I)$ of the $P A L$, promoter. Journal of Plant Growth Regulation, v.36, n.2, p.424-435, 2017. https://doi.org/10.1007/s00344-016-9650-x
GEHRIG, H.; GAUSSMANN, O.; MARX, H.; SCHWARZOTT, D.; KLUGE, M. Molecular phylogeny of the genus Kalanchoe (Crassulaceae) inferred from nucleotide sequences of the ITS-1 and ITS-2 regions. Plant Science, v.160, n.5, p.827-835, 2001. https://doi. org/10.1016/S0168-9452(00)00447-7

GONZÁLEZ DE LEÓN, S.; HERRERA, I.; GUEVARA, R. Mating system, population growth, and management scenario for Kalanchoe pinnata in an invaded seasonally dry tropical forest. Ecology and Evolution, v.6, n.13, p.4541-4550, 2016. https://doi.org/10.1002/ece3.2219

GRÜNEBERG, W.; MWANGA, R.; ANDRADE, M.; ESPINOZA, J. Selection methods. Part 5: Breeding clonally propagated crops. In: CECCARELLI, S.; GUIMARÃES, E.P.; WELTZIEN E. (eds.) Plant breeding and farmer participation. Rome: Food and Agriculture Organization of the United Nations, 2009. p.275-322.

HE, Y.; SUN, Y.; ZHENG, R.; AI, Y.; CAO, Z.; BAO, $M$. Induction of tetraploid male sterile Tagetes erecta by colchicine treatment and its application for interspecific hybridization. Horticultural Plant Journal, vol.2, n.5, p.284-292, 2016. https://doi.org/10.1016/j.hpj.2017.01.002

HERNÁNDEZ-MUÑOZ, S.; PEDRAZA-SANTOS, M.E.; LÓPEZ, P.A.; GÓMEZ-SANABRIA, J.M.; MoralesGarcía, J.L. Mutagenesis in the improvement of ornamental plants. Serie Horticultura, v.25, n.3, p.151-167, 2019.

HERRERA, I.; NASSAR, J.M. Reproductive and recruitment traits as indicators of the invasive potential of Kalanchoe daigremontiana (Crassulaceae) and Stapelia gigantea (Apocynaceae) in a Neotropical arid zone. Journal of Arid Environments, v.73, n.11, p.978-986, 2009. https://doi.org/10.1016/j.jaridenv.2009.05.004.

HICKEY, M.; KING, C. 100 families of flowering plants. Cambridge: Cambridge University Press, 1988. 619p.

HULTINE, K.R.; CUSHMAN, J.C.; Williams, D.G. New perspectives on crassulacean acid metabolism biology. Journal of Experimental Botany, v.70, n.22, p.64896493, 2019. https://doi.org/10.1093/jxb/erz465

IAEA. Kalanchoe Mutant Variety Database. 2021. Available at: <https://mvd.iaea.org/\#!Search?Criteria[0] [val] $=$ kalanchoe $>$. Accessed on: Apr 10 2021.

IBRAHIM, R.; AHMAD, Z.; SALLEH, S.; HASSAN, A.A.; ARIFFIN, S. Mutation Breeding in Ornamentals. In: VAN HUYLENBROECK, J. (eds). Ornamental Crops. Handbook of Plant Breeding. Cham: Springer, 2018. p.175-211.

IZUMIKAWA, Y.; NAKAMURA, I.; MII, M. Interspecific hybridization between Kalanchoe blossfeldiana and several wild Kalanchoe species with ornamental value. Acta Horticulturae, v.743, p.59-65, 2007. https://doi. org/10.17660/ActaHortic.2007.743.7 
IZUMIKAWA, Y.; TAKEI, S.; NAKAMURA, I.; MII, M. Production and characterization of inter-sectional hybrids between Kalanchoe spathulata and K. laxiflora (=Bryophyllum crenatum). Euphytica, v.163, n.1, p.123130, 2008. https://doi.org/10.1007/s10681-007-9619-8

JELOUDAR, N.I.; CHAMANI, E.; SHOKOUHIAN, A.A.; ZAKARIA, R.A. Induction and identification of polyploidy by colchicine treatment in Lilium regale. Cytologia, v.84, n.3, p.271-276, 2019. https://doi.org/10.1508/ cytologia. 84.271

JEPSEN, K.; CHRISTENSEN, E. Method for breeding double-type Kalanchoe interspecific hybrids, 2010. Available at: <https://patents.google.com/patent/ US7847150>. Accessed on: May $10^{\text {th }} 2020$.

KANG, D.I.; JEONG, H.K.; PARK, Y.G.; JEONG, B.R. Flowering and morphogenesis of kalanchoe in response to quality and intensity of night interruption light. Plants, v.8, n.4, p.90, 2019. https://doi.org/10.3390/plants 8040090

KLUGE,M.; BRULFERT, J.; LIPP, J.; RAVELOMANANA, D.; ZIEGLER, H.A. Comparative study by $\delta 13 \mathrm{C}$ analysis of Crassulacean Acid Metabolism (CAM) in Kalanchö̈ (Crassulaceae) species of Africa and Madagascar. Botanica Acta, v.106, n.4, p.320-324, 1993. https://doi. org/10.1111/j.1438-8677.1993.tb00755.x

KRUPA-MALKIEWICZ, M. Influence of chemical mutagens on morphological traits in kalanchoe (Kalanchoe hybrida). Folia Pomeranae Universitatis Technologiae Stetinensis. Agricultura, Alimentaria, Piscaria et Zootechnica, v.15, p.11-18, 2010.

KUANG, Y.; LU, C.H.; HSU, F.C. Restoring fertility for novel interspecific hybrids between Kalanchoe garambiensis and $K$. Nyikae using colchicine treatment. Plants, v.10, n.2, p.1-16, 2021. https://doi.org/10.3390/ plants 10020209

KULIGOWSKA, K.; LÜTKEN, H.; CHRISTENSEN, B.; SKOVGAARD, I.; LINDE, M.; WINKELMANN, T.; MÜLLER, R. Evaluation of reproductive barriers contributes to the development of novel interspecific hybrids in the Kalanchoë genus. BMC Plant Biology, v.15, n.1, p.1-15, 2015a. https://doi.org/10.1186/s12870-014-0394-0

KULIGOWSKA, K.; LÜTKEN, H.; CHRISTENSEN, B.; MÜLLER, R. Quantitative and qualitative characterization of novel features of Kalanchoë interspecific hybrids. Euphytica, v.205, n.3, p.927-940, 2015b. https://doi. org/10.1007/s10681-015-1441-0

KULIGOWSKA, K.; LÜTKEN, H.; CHRISTENSEN, B.; MÜLLER, R. Interspecific hybridization among cultivars of hardy Hibiscus species section Muenchhusia. Breeding Science, v.66, n.2, p.300-308, 2016a. https://doi. org/10.1270/jsbbs.66.300
KULIGOWSKA, K.; LÜTKEN, H.; MÜLLER, R. Towards development of new ornamental plants: status and progress in wide hybridization. Planta, v.244, n.1, p.1-17, $2016 \mathrm{~b}$. https://doi.org/10.1007/s00425-016-2493-7

KUMAR, V.; SHARMA, A.; SONI, J.K.; PAWAR, N. Physiological response of $\mathrm{C} 3, \mathrm{C} 4$ and CAM plants in changeable climate. The Pharma Innovation, vol.6, n.9, p.70-79, 2017.

LAFON-PLACETTE, C.; KÖHLER, C. Endosperm based postzygotic hybridization barriers: developmental mechanisms and evolutionary drivers. Molecular Ecology, v.25, n.11, p.2620-2629, 2016. https://doi.org/10.1111/ mec. 13552

LI, Y.R.; LIU, L.; WANG, D.; CHEN, L.; CHEN, H. Biological effects of electron beam to target turning X-ray (EBTTX) on two freesia (Freesia hybrida) cultivars. PeerJ, v.28, n.9, 2021. https://doi.org/10.7717/peerj.10742.

LIAN, X.; LUO, G.; LI, H.; XU, W.; XIAO, Y.; BI, $X$. Reciprocal difference of interspecific hybridization between three different colours of Iris dichotoma and I. domestica. The Journal of Horticultural Science and Biotechnology, v.91, n.5, p.483-490, 2016. https://doi.org/ $10.1080 / 14620316.2016 .1173525$

LÜTKEN, H.; CLARKE, J.L.; MÜLLER, R. Genetic engineering and sustainable production of ornamentals: Current status and future directions. Plant Cell Reports, v.31, n.7, p.1141-1157, 2012a. https://doi.org/10.1007/ s00299-012-1265-5

LÜTKEN, H.; JENSEN, L.S.; TOPP, S.H.; MIBUS, H.; MÜlleR, R.; RASMUSSEN, S.K. Production of compact plants by overexpression of AtSHI in the ornamental Kalanchoё. Plant Biotechnology Journal, v.8, n.2, p.211-222, 2010. https://doi.org/10.1111/j.14677652.2009.00478.x

LÜTKEN, H.; LAURA, M.; BORGHI, C.; ØRGAARD, M.; ALLAVENA, A.; RASMUSSEN, S.K. Expression of KxhKN4 and KxhKN5 genes in Kalanchoë blossfeldiana "Molly" results in novel compact plant phenotypes: Towards a cisgenesis alternative to growth retardants. Plant Cell Reports, v.30, n.12, p.2267-2279, 2011. https:// doi.org/10.1007/s00299-011-1132-9

LÜTKEN, H.; WALLSTRÖM, S.V.; JENSEN, E.B.; CHRISTENSEN, B.; MÜLLER, R. Inheritance of rol-genes from Agrobacterium rhizogenes through two generations in Kalanchoё. Euphytica, v.188, n.3, p.397-407, 2012b. https://doi.org/10.1007/s10681-012-0701-5

MACKENZIE, K.K.; COELHO, L.L.; LÜTKEN, H.; MÜLLER, R. Phylogenomic analysis of the PEBP gene family from Kalanchoë. Agronomy, v.9, n.4, p.171, 2019. https://doi.org/10.3390/agronomy9040171 
MACKENZIE, K.K.; LÜTKEN, H.; COELHO, L.L.; KAABER, M.D.; HEGELUND, J.N.; MÜLLER, R. Kalanchoё. In: VAN HUYLENBROECK, J. (eds). Ornamental Crops. Handbook of Plant Breeding. Cham: Springer, 2018. p.453-479.

MENDOZA-GÓMEZ， R.J.; TAPIA-CAMPOS， E.; BARBA-GONZALEZ, R. In vitro mutagenesis efficiency with EMS (ethyl methanesulfonate) on Eustoma grandiflorum. Acta Horticulturae, v.1288, p.163-166, 2020. https://doi.org/10.17660/ActaHortic.2020.1288.24

MIBUS, H. Breeding and genetics for shelf and vase life. In: VAN HUYLENBROECK, J. (eds). Ornamental Crops. Handbook of Plant Breeding, vol 11. Cham: Springer, 2018. p.63-95.

MOSTAFA, G.G.; MOHAMED, M.A.; ALY, M.K.; RAMADAN, H.A. Evaluation of Chrysanthemum morifolium cv. Maghi plants after sodium azide treatment. Scientific Journal of Agricultural Sciences, v.1, n.1, p.14-20, 2019. https://doi.org/10.21608/SJAS.2019.52804

NIAZIAN, M.; NALOUSI, A.M. Artificial polyploidy induction for improvement of ornamental and medicinal plants. Plant Cell, Tissue and Organ Culture, v.142, p.447-469, 2020. https://doi.org/10.1007/s11240-02001888-1

PATIL, U.H.; KARALE, A.R.; KATWATE, S.M.; PATIL, M.S. Mutation breeding in chrysanthemum (Dendrathema grandiflora T.). Journal of Pharmacognosy and Phytochemistry, v.6, n.6, p.230-232, 2017.

PERRIER DE LA BATHIE, H. Les pestes végétales à Madagascar. Journal d'agriculture traditionnelle et de botanique appliquée, v.8, n.77, p.36-43, 1928.

PRAMANIK, K.; SAHOO, J.P.; MOHAPATRA, P.P.; ACHARYA, L.K.; JENA, C. Insights into the embryo rescue-a modern in-vitro crop improvement approach in horticulture. Plant Cell Biotechnology and Molecular Biology, v.22, n.15\&16, p.20-33, 2021.

PURENTE, N.; CHEN, B.; LIU, X.; ZHOU, Y.; He, M. Effect of ethyl methanesulfonate on induced morphological variation in M3 generation of Chrysanthemum indicum var. aromaticum. Journal of the American Society for Horticultural Science, v.55, n.7, p.1099-1104, 2020. https://doi.org/10.21273/HORTSCI15068-20

QUEEN FLOWERS. Kalanchoe. 2021. Available at: $<$ https://queenflowers.dk/en>. Accessed on: Feb 5 2021.

RANGSLANG, R.K.; LIU, Z.; LÜTKEN, H.; FAVERO, B.T. Agrobacterium spp. genes and ORFs: mechanisms and applications in plant science. Ciencia e Agrotecnologia, v.42, n.5, p.453-463, 2018. https://doi.org/10.1590/141370542018425000118
ROYAL FLORAHOLLAND. Facts \& figures. 2021. Available at: <https://www.royalfloraholland.com/ media/15219125/royal-floraholland-facts-andfigures-2020.pdf.> Accessed on: Mar 30 2021.

ROYAL HORTICULTURE SOCIETY. Cacti and succulents. 2021. Available at: <https://www.rhs.org.uk/ advice/profile?PID=849>. Accessed on: Jan $4^{\text {th }} 2021$.

RUNGRUCHKANONT, K.; PROMCHOT, T. Role of plant growth regulators on fruit set and embryo culture of interspecific Phalaenopsis. Acta Horticulturae, v.1167, p.119-126, 2016. https://doi.org/10.17660/ ActaHortic.2017.1167.18

SANIKHANI, M.; MIBUS, H.; STUMMANN, B.M.; SEREK, M. Transformation of Kalanchoe blossfeldiana for ethylene insensitivity. v.847, p.103108, 2009. Acta Horticulturae. https://doi.org/10.17660/ ActaHortic.2009.847.12

SATTLER, M.C.; CARVALHO, C.R.; CLARINDO, W.R. The polyploidy and its key role in plant breeding. Planta. v.243, p.281-296, 2016. https://doi.org/10.1007/s00425$015-2450-\mathrm{x}$

SAWADA, Y.; SATO, M.; OKAMOTO, M.; MASUDA, J.; YAMAKI, S.; TAMARI, M.; TANOKASHIRA, Y.; KISHIMOTO, S.; OHMIYA, A.; ABE, T.; HIRAI, M.Y. Metabolome-based discrimination of chrysanthemum cultivars for the efficient generation of flower color variations in mutation breeding. Metabolomics, v.15, n.9, 2019. https://doi.org/10.1007/s11306-019-1573-7

SIREGAR, H.M. Four new varieties of Begonia from interspecific hybridization Begonia natunaensis C.W.Lin \& C.I.Peng $\tilde{A}$ - Begonia puspitae Ardi. Biodiversitas Journal of Biological Diversity, v.17, n.2 p.776-782, 2016. https://doi.org/10.13057/biodiv/d170254

SLIJKERMAN®. Kalanchoë. 2021. Available at: < https:// www.slijkerman.nl/>. Accessed on: May 30 2021.

SMITH, G.F.; FIGUEIREDO, E.; VAN WYK, A.E. Kalanchoe (Crassulaceae) in Southern Africa: Classification, Biology, and Cultivation. London: Academic Press, 2019. 328p.

SU, J.; JIANG, J.; ZHANG, F.; LIU, Y.; DING, L.; CHEN, S.; Chen, F. Current achievements and future prospects in the genetic breeding of chrysanthemum: a review. Horticulture Research, vol.6, n.1, p.1-19, 2019. https:// doi.org/10.1038/s41438-019-0193-8

SUN, C.; MA, Z.; ZHANG, Z.; SUN, G.; DAI, Z. Factors influencing cross barriers in interspecific hybridizations of water lily. Journal of the American Society for Horticultural Science, v.143, n.2, p.130-135, 2018. https://doi.org/10.21273/JASHS04302-17 
TAKAMURA, Y.; ASANO, C.; HIKAGE, T.; HATAKEYAMA, K.; TAKAHATA, Y. Production of interspecific hybrids between Japanese gentians and wild species of Gentiana. Breeding science, v.69, n.4, p.680687, 2019. https://doi.org/10.1270/jsbbs.19115

THIRUKKUMARAN, G.; KHAN, R.S.; CHIN, D.P.; NAKAMURA, I.; MII, M. Isopentenyl transferase gene expression offers the positive selection of marker-free transgenic plant of Kalanchoe blossfeldiana. Plant Cell, Tissue and Organ Culture, v.7, n.3, p.237-242, 2009. https://doi.org/10.1007/s11240-009-9519-9

TRAORÉ, L.T.; KULIGOWSKA, K.; LÜTKEN, H.; MÜLLER, R. Stigma development and receptivity of two Kalanchö̈ blossfeldiana cultivars. Acta Physiologiae Plantarum, v.36, n.7, p.1763-1769, 2014. https://doi. org/10.1007/s11738-014-1550-8

VAN HUYLENBROECK, J. Breeding for sustainable ornamental plants. Acta Horticulturae, n.1288, p.1-8, 2020. https://doi.org/10.17660/ActaHortic.2020.1288.1

VAN VOORST, A.; ARENDS, J.C. The origin and chromosome numbers of cultivars of Kalanchoe blossfeldiana Von Poelln.: Their history and evolution. Euphytica, v.31, n.3, p.573-584, 1982. https://doi. org/10.1007/BF00039195

VON POELLNITZ, K. Kalanchoe blossfeldiana. Repertorium novarum specierum regni vegetabilis, v.35, n.8-17, p.159-160, 1934. https://doi.org/10.1002/ fedr. 19340350803
WANNAJINDAPORN, A.; KATIVAT, C.; TANTASAWAT, P.A. Mutation induction of Dendrobium 'Earsakul'using sodium azide. Journal of the American Society for Horticultural Science, v.51, n.11, p.1363-1370, 2016. https://doi.org/10.21273/HORTSCI10860-16

XIE, W.J.; LEUS, L.; WANG, J.H.; VAN LAERE, K. Fertility barriers in interspecific crosses within Viburnum. Euphytica, v.213, n.2, p.1-18, 2017. https://doi. org/10.1007/s10681-016-1829-5

XING, G.; QU, L.; ZHANG, W.; ZHANG, Y.; YUAN, X.; LEI, J. Study on interspecific hybridization between tulip cultivars and wild species native to China. Euphytica, v.216, n.4, p.1-17, 2020. https://doi.org/10.1007/s10681020-02594-X

YANG, X.; HU, R.; YIN, H.; JENKINS, J.; SHU, S.; TANG, H.; TUSKAN, G.A. The Kalanchoë genome provides insights into convergent evolution and building blocks of crassulacean acid metabolism. Nature Communications, v.8, n.1, p.1-15, 2017. https://doi.org/10.1038/s41467-01701491-7

ŻABICKA, J.; MIGDAŁEK, G.; SŁOMKA, A.; SLIWINSKA, E.; MACKIEWICZ, L.; KECZYŃSKI, A.; KUTA, E. Interspecific hybridization and introgression influence biodiversity-based on genetic diversity of Central European Viola epipsila-V. palustris complex. Diversity, v.12, n.9, 2020. https://doi.org/10.3390/d12090321

ZEEVAART, J.A.D. Bryophyllum. CRC Handbook of Flowering. Boca Raton: CRC Press, 1985. p.89-100. 